\title{
Research on Construction Technology of Concrete in Winter for Deep Foundation Pit by Top-Down Construction Method
}

\author{
Dong Li \\ College of Civil Engineering \\ Hebei University of Technology \\ Tianjin, China \\ purelee@163.com
}

\author{
Lianyu Wei \\ College of Civil Engineering \\ Hebei University of Technology \\ Tianjin, China \\ wly57@126.com
}

\begin{abstract}
In the most of the cold regions of the Northern Hemisphere, three even six months are cold season every year. In order to meet the needs of the project schedule, a large number of construction engineering are still advanced in winter. The low temperature can cause cast-in-situ concrete component of early frost, greatly reduce its safety and durability, therefore, must be on the winter concrete engineering to take corresponding measures to ensure the smooth construction of concrete. It is necessary to extend the protection period. However, it had better finish the course of concrete construction quickly to the Top-Down construction method. This is a contradiction which is very difficult to solve. This paper points out the characteristics of concrete engineering construction in winter, describes the basic principles and methods of concrete engineering construction in winter and the characteristics of the deep foundation pit by Top-Down construction method, and discusses this contradiction about the speed of concrete construction. At last, this paper gives the technical measures and management measures to solve this problem. Through the research of this paper, some meaningful conclusions are received, which can provide the reference for the other constructions.
\end{abstract}

Keywords-Deep Foundation Pit; Top-down Construction Method; Concrete; Winter Construction; Technical Measures;

\section{INTRODUCTION}

With the rapid development of the world economy and the rapid speed-up of the urbanization, there are many big cities or especially big cities come into being. To solve the problem of shortage of land resources, high-rise buildings appear. Meanwhile they are accompanied by a large number of deep foundation pits. In some cities, due to limitations of the construction area, deep foundation pit construction often uses top-down method. Generally compared to the part of building over the horizon, underground construction project will face more complex situation. The technology of top-down method demands stricter standard. It is more difficult to construct. The various research of deep pit foundation by top-down method has gradually become a hot topic. Among these problems, construction of concrete in winter is one of these problems for deep foundation pit by top-down construction method.

In order to ensure the continuity and the request of progress of the construction, the building practitioners are often forced to construct in hard construction environment hypothermia. This thing is very common in the northern hemisphere. For example, in China the time tableau of concrete construction in winter is as follow table I. This shows that the proportion of the time of construction in winter is great. Even in Shanghai region, it is about 2.5 months. As we all know, when the concrete is in the situation at low temperatures, it is not beneficial to protect the quality of concrete. Therefore, the research of this paper about to analyze how to ensure the quality of concrete that get on in winter systematically gives some proposed solutions specifically. They can be important reference and a practical guide.

TABLE I. THE TIME OF CONCRETE CONSTRUCTION IN WINTER IN CHINA

\begin{tabular}{|c|c|c|c|}
\hline region & start time & end time & duration \\
\hline Northeast region & Early in October & Early in Mai next year & 7 months \\
\hline Northwest region & Early in November & Mid in March next year & 6 months \\
\hline Tibet region & Late in October & Early in Mai next year & 6.5 months \\
\hline Xinjiang region & Mid in October & Late in April next year & 4.5 months \\
\hline Beijing region & Late in October & Early in April next year & 2.5 months \\
\hline Shanghai region & Mid in December & Early in March next year & \\
\hline
\end{tabular}




\section{DEEP FOUNDATION PIT BY TOP-DOWN CONSTRUCTION METHOD}

To the deep foundation pit, the so-called top-down construction method is relative to the most in terms of deep foundation pit construction sequence. Its sequence is supporting structure, earth excavation, cushion and bottom plate, structural column and roof support. Then we repeat this sequence: structural column, roof support until plus or minus zero position. In simple terms we construct from top to bottom. That is to say, firstly we conduct in the basement floor construction, taking advantage of floor to support the excavation. We can continue to construct the other part of the excavation down.

Top-down construction method is getting more and more application, as an effective method. However, this method has complex construction organization and many courses. Whether on theory or practice, there are quite lot of problems and questions need to be solved. Construction of concrete is one of these problems. To the top-down method, before the structure of basement forms, the foundation pit has been excavated. For this moment, the effect of the soil and water is the strongest to the foundation pit. So we hope that the structure of basement has strength as quickly as possible. In other word, construction concrete is finished as quickly as possible. Then we can ensure the stability of the whole building by this way.

\section{THE CHARACTERISTIC OF CONCRETE CONSTRUCTION IN WINTER}

Concrete is a kind of composite material which is made of cementations materials, water, aggregate and other admixtures. Initially it's liquid mixture, and then cement and water react. In this process, there are a lot of heats of hydration. At last concrete hardens gradually. It turns into solid that has strength and stiffness. However, water is liquid in the normal temperature, the solid in temperature below zero. So there should be completely different approach for concrete construction in winter. The temperature is a very important factor. As soon as temperature rises, Hydration reaction speeds up. Concrete will has strength quickly. On the contrary, when temperature falls in subzero, water will turn into solid. Not only there is hydration reaction, but also there will the volume of water expand about $9 \%$. This produces frost stress and destroys concrete strength. It will also weaken the bond strength between concrete and steel and impact the compressive strength of reinforced concrete. After the temperature rises, the water turns into liquid from solid. Its volume decreases. There will be many gaps inside the concrete, reducing the density and durability of concrete. So we must pay attention to the changes of water in winter. Or else it is very easy to be damaged for concrete. We need to take measures for increasing concrete curing. At the same time, we need to extend the time of construction in this course.

In summary, according to the characteristics of topdown construction method, it's the moment when the soilwater effect makes the most destructive results, when the basement is constructed. It is required that basement structure should be completed as soon as possible, in order to provide stiffness and support for the security of foundation pit. However, if the construction takes place in winter, the quick construction is not in favor of concrete curing. In addition, construction of deep foundation pit belongs to large bulk concrete construction. It is a contradiction that is solved difficultly. This is the difficulty to construction in winter for deep foundation pit by top-down method. There is no effective and ideal method currently. This paper recommends some measures based on research and summaries in practice.

\section{THE TECHNICAL MEASURES}

To the construction of deep foundation excavation, when excavation approach to the bottom of foundation pit, we must take care for over breaking which can damage to the substrate undisturbed soil structure. When we use machine to cut, we must stop in the site poor $20 \mathrm{~cm}$ to the bottom. Then we will continue cutting artificially. Before backfilling soil, we will take care of wind and rain erosion, sun, weathering, freeze-thaw action, displacement, deforming and etc.

To the ground and foundation engineering, we need to pay attention to control points, benchmark and axis of anchor point. When we embed them, we must take steps to prevent the effects of frost heaving of soil, melt settlement deformation and construction vibration. At the same time, we need to retest and correct regularly.

To concrete construction, we must use commercial concrete and ensure the temperature of concrete isn't lower than $10^{\circ} \mathrm{C}$ before pouring the template, the speed of hypothermia of concrete is $5^{\circ} \mathrm{C} / \mathrm{h}$ at most. We place the concrete as much as possible in the moment from 9:00 to 16:00. If it snow, we need cover plastic sheeting over the steels that we have banded steels and clean ice or snow on the template before placing. In addition we need bundle the flame retardant rock wool all over the pump line in winter.

To the concrete curing in winter, we need ensure that temperature difference between inside and outside the concrete is no more than $25^{\circ} \mathrm{C}$. For heat preservation, we usually cover plastic sheet firstly, and then cover the rock wool, at last brush curing liquid.

To the template removal, we decide when we will remove templates according to the situation of concrete samples that are cured with the same standards. The strength of concrete must arrive in critical frost strength. The critical frost strength is not certain. It is different in different country or different region. It's $4 \mathrm{MPa}$ in Tianjin China.

To steel bar project, we must take care some of the issues, because mechanical property of steel will change in freezing-thawing environment, such as increase of strength and yield point, dropping of elongation and impact toughness. Therefore we try to avoid collision and extrusion when we transport, pile up or carry steel. When we reinforce steel, we must ensure that bending radius is more than four times the diameter of the steel and not bend repeatedly in the same site and not bend steel using electricity. To the degree more than $\varphi 22$, we use straight thread to weld. To less than $\varphi 22$, we use language binding method to connecting reinforcement. We may choice flush butt welding, arc welding or gas pressure welding in freezing-thawing environment. However, when the temperature is less than $-20^{\circ} \mathrm{C}$, we must stop welding work. 
Compared to construction in the others seasons, we must adjust the mix proportion of the concrete. In Beijing region, the content of coal ash will decrease $4-7 \%$ generally. The aggregate will be increased. For example, the table about the change and contrast of the mix proportion of the concrete in Beijing region as follow table II. The strength of concrete is calculated as follow (1).

$$
f_{\text {cu.o }}=f_{\text {cu.k }}+1.645 \sigma
$$

The water-cement ratio is calculated as follow (2).

$$
W / C=\left(a_{a} \cdot f_{c e}\right) /\left(f_{\text {cu.o }}+a_{a} \cdot a_{b} \cdot f_{c e}\right)
$$

The water consumption is $m_{w \cdot p}=170 \mathrm{Kg} / \mathrm{cm}^{3}$. The cement consumption is calculated as follow (3).

$$
m_{\text {c.o }}=m_{\text {w.p }} /(W / C)
$$

The sand consumption is calculated as follows (4).

$$
m_{\text {s.o }}=\beta_{s}\left(m_{c p}-m_{c . o}-m_{w . o}\right)
$$

The stone consumption is calculated as follows (5).

$$
m_{g . o}=\left(1-\beta_{s}\right)\left(m_{c p}-m_{c . o}-m_{w . o}\right)
$$

TABLE II. THE CONTRAST OF MIX PROPORTION OF CONCRETE IN BEIJING REGION

\begin{tabular}{|c|c|c|c|c|}
\hline \multirow{2}{*}{ variety } & \multicolumn{2}{|c|}{ C50F350(pile) } & \multicolumn{2}{c|}{ C45F300(beam) } \\
\cline { 2 - 5 } & others & winter & others & winter \\
\hline Cement $/\left(\mathrm{Kg} \cdot \mathrm{m}^{-3}\right)$ & 323 & 342 & 314 & 336 \\
\hline Coal Ash $/\left(\mathrm{Kg} \cdot \mathrm{m}^{-3}\right)$ & $\begin{array}{c}131 \\
(28 \%)\end{array}$ & $\begin{array}{c}94.5 \\
(21 \%)\end{array}$ & $\begin{array}{c}115 \\
(26 \%)\end{array}$ & $\begin{array}{c}98.5 \\
(22 \%)\end{array}$ \\
\hline Ganister Sand $/\left(\mathrm{Kg} \cdot \mathrm{m}^{-3}\right)$ & $13(4 \%)$ & $13.7(4 \%)$ & $12.6(4 \%)$ & $13.4(4 \%)$ \\
\hline Sand $/\left(\mathrm{Kg} \cdot \mathrm{m}^{-3}\right)$ & 523 & 537 & 538 & 537 \\
\hline Stone $/\left(\mathrm{Kg} \cdot \mathrm{m}^{-3}\right)$ & 1219 & 1253 & 1255 & 1253 \\
\hline Water Reducer $/\left(\mathrm{Kg}^{-3} \mathrm{~m}^{-3}\right)$ & 9.81 & 15.8 & $\begin{array}{c}9.27 \\
(2.1 \%)\end{array}$ & \begin{tabular}{c}
$3.5 \%)$ \\
\hline Air Entraining Agent $/\left(\mathrm{Kg}^{-3} \mathrm{~m}^{-3}\right)$
\end{tabular} \\
\hline Mixing Water $/\left(\mathrm{Kg} \cdot \mathrm{m}^{-3}\right)$ & 1.75 & $\begin{array}{c}1.68 \\
(0.012 \%)\end{array}$ & $\begin{array}{c}1.65 \\
(0.012 \%)\end{array}$ & $\begin{array}{c}0.012 \%) \\
(0.012 \%)\end{array}$ \\
\hline Water-Binder Ratio & 149 & 139 & 138 & 139 \\
\hline
\end{tabular}

\section{THE MANAGEMENT MEASURES}

Prefer to use the Portland cement or ordinary Portland cement. The degree of the concrete strength is more than $32.5 \mathrm{MPa}$. The water-cement ratio is less than 0.6. There is no snow or ice in the coal ash. The mixing water is qualified after assay.

When the temperature outdoor isn't less than $-15^{\circ} \mathrm{C}$, the degree of the concrete strength maintains more than $4.0 \mathrm{~N} / \mathrm{m}^{3}$; When the temperature outdoor isn't less than $30^{\circ} \mathrm{C}$, it maintains more than $5.0 \mathrm{~N} / \mathrm{m}^{3}$

Arrange the temperature measurement work on site well, distribute the responsibilities to the people and establish a special department of concrete construction in winter.

Laboratory worker is responsible to listen to weather forecasts and meteorological records everyday. To master the recent change of the temperature, we need to transmit and report meteorological information timely. They are for take timely measures, when the sudden change of temperature.
Arrange someone to measure regularly the temperature of the discharge port and the concrete during the course of construction when it is in the maximum daily air temperature and the minimum temperature.

In order to realize the development of the strength of concrete in winter, it is required that we produce a group of test piece which is same with the building.

In the concrete pouring process, project management staffs need to day and night shift and unscheduled inspect of the construction.

\section{CONCLUSIONS}

The measures above have been applied successfully in several constructions in Tianjin. For example, the foundation pit of Wante Commercial in Tianjin China, underground structure of Tianjin electric power, deep excavation of the first period of Tianjin hospital renovation and expansion engineering, etc. We can draw the following preliminary discourse:

These measures are useful to ensure the quality of the concrete in winter;

These measures can be popularized in cold region;

These measures need to be researched by theory; 
We must continue to research following new material and new construction method to solve this problem.

To sum up, to deep foundation pit by top-down method, the quality control research about concrete construction in cold region winter shows that we need to shorten the winter construction period, to speed up the process of project construction. Meanwhile, the project investment does not increase much as far as possible. However, we must try not to construct concrete in winter, or we try to finish the key position and main structure before winter.

\section{REFERENCES}

[1] American Concrete Institute (2009) Building Code Requirements for Reinforced Concrete, ACI 3 18-19. Farmington Hill, Michigan: American Concrete Institute.

[2] Tagnit-Hamou, Arezki. "Cement and superplasticizer compatibility," World Cement. 2013(8): 38-42P

[3] B.Zuber, J.Marchand, A.Delagrave and J.P.Bournazel. "Ice Formation Mechanisms in Normal And HPC Mixtures," Journal of Materials in CivilEngineering. 2010(2): 16-22P
[4] P.K.Mehta, R.W.Burrows. "Building Durable Structures in the 21st Century," Concrete International. 2009(3): 89-91P

[5] Boris A.Krylov. "Cold Weather Concrete," CRC Press. 2007: 41$58 \mathrm{P}$

[6] Kobori T. Mission and Perspective Towards Future Structure Control Research[J]. Proceedings of 2nd World Conference on Structure Control. 2008

[7] Symans M D,Reigles D G Supervisory fuzzy logic control of smart seismic isolation systems, Proceedings of 2014 ASCE Structural Congress, Nashville TN,2014.

[8] Yang G. Large-Scale Magnetorheological Fluid Damper for Vibration Mitigation: Modeling, Testing and Control.ph.D Dissertation University of Nortre Dame.2011.

[9] Bungey, J.H., Millard, S.Gand Grantham, M.G.(2009)Testing of Concrete in Structures. New York: Taylor \& Francis

[10] A.R.Mitchell,C.Izumi.Semi top-down construction method for Singapore MRT,NET.Tunels and Underground Structures.2010.

[11] Seth L.Pearlman,P.E.Deep Underground Basements for Major Urban Building Construction. GEOSUPPORT 2009. 